einen Apparat verfügt, der die Dorfebene erreicht. Nicht selten existieren Parteien nur auf dem Papier oder haben einen Radius, der über die Hauptstadt kaum hinausreicht.

Das Handbuch gibt einen guten Überblick über die Parteienlandschaft, wie sie sich bis zum Redaktionsschluß (Juni 1992) präsentierte. Eine Anschaffung kommt - wegen des relativ hohen Preises - eher für Bibliotheken in Betracht, das Buch sollte dort aber nicht fehlen.

Heiko Meinhardt

\title{
Catherina Lax
}

\section{Die Mongolei im strategischen Kräftefeld Asiens. Vom Einparteienstaat zur pluralistischen Demokratie}

Nomos Verlagsgesellschaft, Baden-Baden, 1995, 404 S., DM 88,--

The United States and Mongolia, as a Mongolian politician once remarked to the US Secretary of State at the time of the Gulf war against Iraq, have both achieved the conquest of Baghdad. Today's Mongolia is a long way from its heyday of Kublai Khan and dominions reaching from the Middle East to the Amur river. But since the demise of the communist government and the end of Soviet tutelage the country, wedged in between her giant neighbours, Russia and China, "like an egg between two rocks", has embarked on a cautious course of reform and recovery of national independence. In contrast to the rapidly expanding economies of East and Southeast Asia, Mongolia, with a population of roughly two million and a territory more than four times the size of reunified Germany, is still overwhelmingly agrarian and saddled with a legacy of former dependence on the defunct Soviet Union, long Mongolia's principal trading partner.

While the Pacific Rim "tigers" have provoked a spate of media and scholarly attention, the same cannot be said of post-communist Mongolia, and Dr. Lax's monograph, arranged in succinct handbook style, provides a convenient introduction both to the modern history of the country and to contemporary developments. An opening chapter gives a brief overview on basic features and data. The subsequent chapters describe the varying fortunes of Mongolia under the rule of the last imperial Chinese dynasty (the Ch'ing), the creation of the soviet republic in the wake of the collapse of the Ch'ing and the overthrow of the Tsarist regime in Russia and, finally, the long spell of Eastern-bloc authoritarianism, planned economy and subservience to USSR hegemony. Much space is devoted to a critical discussion of USSR Leninist ideological rationalisation of Soviet Russian interference and overlordship in Mongolia conveying at the same time, to a post-USSR readership, the particularly trite and bombastically self-serving verbiage of "proletarian internationalism" alla moscovita. The two concluding chapters deal with Mongolia's foreign relations and the changes since 1992, inspired by Gorbachev's perestroika. A bibliography lists numerous works, in Western languages and Russian; an extensive annexe contains a 
translation into German of the 1992 constitution of the Mongolian People's Republic, the text of the 1986 German-Mongolian agreement on cultural co-operation as well as several statistical tables on the country's economy and a list of addresses of various commercial entities in Mongolia and Germany.

Dr. Lax's book is a welcome reader for those seeking quick initial reference on modern Mongolia and her historical background. Perhaps too much information of merely ephemeral value has been included: Data such as names of members of the Mongolian cabinet, of the Mongolian and German ambassadors in either country or prominent official visitors from both states will naturally soon be out of date, and the same applies to statistical figures. More importantly, the treatment of Mongolia in the context of "Asian" politics as intimated by the book's title largely concentrates on relations with (Soviet) Russia. China, as the other neighbour looming large on the southern borders, and, to a lesser extent, Japan receive much briefer attention, in chapter 10 on foreign relations (incidentally, "Mandschukuo", p. 201, i.e. Manchoukuo [variantly spelled "Mandchoukouo" at p. 230], "and China" is not a formula that would be well received on either side of the Taiwan Strait).

The future course of Mongolian domestic progress and foreign relations will be of considerable importance to the entire Asian region. Ancient ties, as between the Lamaist Buddhism of Tibet and the attendant spiritual authority of the Dalai Lama not only in his homeland but also in a Mongolia where Buddhism has seen a rapid renaissance after the former Stalinist destruction of that religion, have already revived affinities which might well be viewed with suspicion in Peking. Economic success of a reforming Mongolia could also change the country's image in the eyes of those Mongolians in Chinese "Inner Mongolia", who today are a minority of about three-and-a-half million alongside over sixteen million Han Chinese. The book under review should serve as a useful work aid to those who wish to follow developments in Central Asia.

Wolfgang Kessler

\author{
Asghar Shirazi \\ Die Widersprüche in der Verfassung der Islamischen Republik vor dem \\ Hintergrund der politischen Auseinandersetzung im nachrevolutionären Iran \\ Ethnizität und Gesellschaft: Occasional Papers Nr. 32 \\ Verlag Das Arabische Buch, Berlin, 1992, 102 S.
}

Die Verfassung der Islamischen Republik Iran $^{1}$ ist ein Produkt der Islamischen Revolution und reflektiert in ihren Widersprüchlichkeiten eine bestimmte Phase des Umbruchpro-

1

Vgl. dazu Tellenbach, Untersuchungen zur Verfassung der Islamischen Republik Iran vom 15. November 1979 (1985). 